\title{
自家用車利用からバス利用への転換可能性と バスサービスに対する改善ニーズ
}

\author{
氏原 岳人 1 ・阿部 宏史 2 ・柏村 友哉 3 \\ 1正会員 岡山大学大学院助教 環境生命科学研究科（干700-8530 岡山県岡山市北区津島中3-1-1） \\ E-mail: ujihara@cc.okayama-u.ac.jp \\ 2正会員 岡山大学大学院教授 環境生命科学研究科（†700-8530 岡山県岡山市北区津島中3-1-1） \\ E-mail: abe1@cc.okayama-u.ac.jp \\ 3非会員＼cjkstart神戸市役所（广650-8570 兵庫県神戸市中央区加納町6-5-1） \\ E-mail: ev20214@s.okayama-u.ac.jp
}

\begin{abstract}
地域の身近な足として，また環境負荷の低い（輸送量あたりの $\mathrm{CO}_{2}$ 排出量の少ない）移動手段として “バス交通”が期待されている。一方, バス利用者数は年々減少傾向にあり, 存続のためには, 自家用車 利用からの転換が特に重要となる。 そこで本研究では, 自家用車利用からバス利用への潜在的な転換可能 性や，その際のバスサービスの改善ニーズを，居住者のバス利用環境の視点から定量的に明らかにした. 分析の結果，バス利用の有無やバス利用への転換可能性は，年齢層及び職業の有無等の個人属性や居住地 周辺のバス整備状況が特に影響していることが確認できた。 さらに，バス利用へ転換する場合に改善を求 めるバスサービスは，40代以下の層は，運行システムなどで相対的に類似した改善ニーズを持つ一方，60 代以上非勤め人の層は, 乗車前後の負担に関連する特徵的な改善ニーズを有していた.
\end{abstract}

Key Words : buses, modal change, private vehicles, bus service

\section{1. はじめに}

わが国において都市・地域計画や交通計画を進めてい く中で，“地球環境問題” と“人口減少・高齢社会” の対応は喫緊の課題となっている.このような状況の中 で，生活の足となるバス交通の重要性がより一層高まっ ている，その一方で，高度経済成長期以降のモ一タリゼ ーションの進展などを背景にして，バス利用者数は急激 に減少している.このため, 多くのバス事業者は厳しい 経営状況にあり，バスサービスの低下を余儀なくされ， 結果的に更なる利用者数の減少を招くといった “負のス パイラル”に陥っている.

しかしながら，地域のバス交通は，きめ細かなサービ スを提供することができるため，移動制約者の生活交通 としても非常に重要な役割を担っている. バス交通の確 保のために “負のスパイラル”から, “正のスパイラ ル” 転換させるには，バス利用者数の増加が必要条件 であり，バス交通を積極的に利用してもらうような施策 の展開が求められる.とりわけ，自家用車からバス利用 への転換は，エネルギー消費に伴う $\mathrm{CO}_{2}$ 排出量の削減 (1人1キロ移動するのに自家用車と比較して $1 / 3$ 以下の
$\mathrm{CO}_{2}$ 排出量に抑えられる $)$ や，また空間利用効率性が 高く2)交通渋滞の緩和などの社会的な効果を多くもたら すと考えられる。このため，これまでバスをあまり利用 してこなかった層や，自家用車を積極的に利用してきた 層に対して，そもそもバス利用への潜在的な転換可能性 があるのかどうか，ある場合には，どのような人々が， どのようなバスサービスの改善を求めているのかといっ た基本的な情報が実務上必要になる。しかしながら，こ れまでそれら知見について体系的に検討された研究事例 は数少なく, 研究蓄積は十分とは言えない.

そこで本研究では，自家用車利用からバス利用への潜 在的な転換可能性について，バス利用環境（個人属性や バス整備状況など）の視点から検討する. そして，バス 利用への転換可能性のある層が，どのようなバスサービ スの改善を求めているのかを明らかにすることで，バス 交通のモビリティ確保に向けた実務上有益な知見を得る ことを目的としている.

具体的には，典型的な地方中心都市であり，バス利用 者数が年々減少している3岡山県岡山市においてバス利 用に関するアンケート調査を実施し，それら結果に基づ いて，1)「バスを利用する層」と「バスを利用しない 
層」，2)バスサービスの改善により，自家用車利用から バス利用人「転換する可能性がある層」と「転換する可 能性がない層」について，それぞれ個人のバス利用環境 の視点から傾向を把握する. 最後に，3)バス利用へ転換 寸る際に，どのようなバスサービスの改善ニーズがある のかについて分析する.

\section{2. 既存研究と本研究の特長}

本章では，自家用車利用からの転換を目的としたバス 利用促進策に関する既存研究を主として整理することで, 本研究の特長と位置づけを明確にする.

まず，交通需要予測を目的とした研究としては，遠藤 ら4によるバスサービス水準の向上やパークアンドバス ライドによる自動車からの転換効果を, 独自に構築した モデルにより推定した研究や, 高木らうによるる行動意図 法を用いた，バスサービス水準向上における潜在需要を 推計した研究等が見られる.これらに対して，個人の意 識レベルの視点からバス利用との関連性を把握する試み も行われており, 萩原らりよる, 行動変容のための行 動プランデータに基づいて自動車利用抑制パターンを明 らかにした研究や，また近年では，倉嶋られによる利用 頻度と路線バスに対するイメージとの関係を明らかにし た研究, 佐藤ら ${ }^{8}$ による接客サービスがバス利用満足度 に与える影響など明らかにした研究がある.このように, 自家用車利用を抑制し，バス利用を向上させるための知 見を得ることを目的とした研究は既に存在している。一 方で, これら研究は, 自家用車からバス利用への転換可 能性に焦点を当て, 個人属性やバス利用環境との関連性, そのための改善ニーズを網羅的に明示した研究ではない.

これらをふまえ，本研究の特長は以下の通りである。

1) バス利用の有無及び自家用車利用からの潜在的な 転換可能性を，個人の属性やバス利用環境を説明 変数とする多変量解析により定量的に明らかにし ている.

2) 個別のバスサービスに対する改善ニーズを，外部 観察可能な個人属性（年齢や職業の有無）に着目 して解析することにより， バス利用一の転換に向 けた実務上の課題を提示している.

3) コレスポンデンス分析を用いることにより，異な る個人属性間での改善ニーズの類似性や特殊性を, 視覚的に分かりや寸く明示している.

\section{3. アンケート調査の概要と使用データ}

本研究で独自に実施したバス利用に関するアンケート
表-1 アンケート調查の概要

\begin{tabular}{|c|c|}
\hline 調查方法 & 自己記入方式 (必要に応じて、聞き取り方式) \\
\hline 対象 & JR岡山駅 駅前広場の利用者（中学生以上） \\
\hline 実施時期 & 2011年11月1日（火）、2日（水）、6日（日） \\
\hline 調査時間 & 午前11時～午後7時 \\
\hline 実施場所 & JR岡山駅 駅前広場 \\
\hline 調査員の人数 & 8人 \\
\hline 回収部数 & 486部(うち、岡山市民227部を本分析で利用) \\
\hline \multirow{5}{*}{ 調査票の構成 } & 1.普段の行動について \\
\hline & 2.交通手段に対する考え方について \\
\hline & 3.バス利用やバスに対する考え方について \\
\hline & 4.自動車利用について \\
\hline & 5.回答者自身について \\
\hline
\end{tabular}

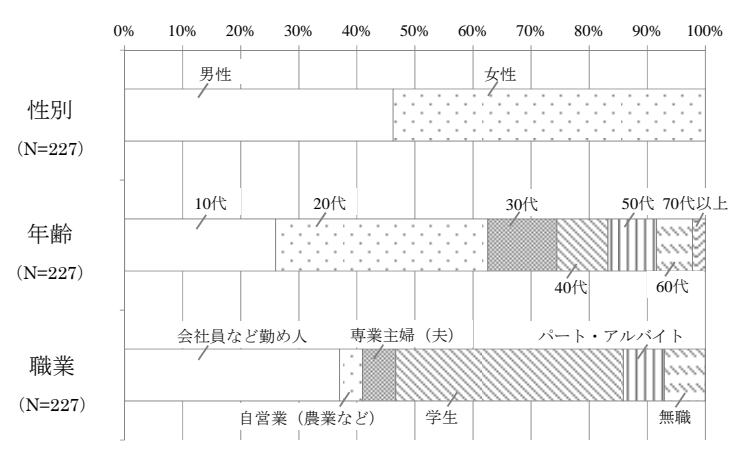

図-1 被験者の個人属性

調査の概要を表-1に示す.

アンケート調查は，JR岡山駅の駅前広場で実施してい る. 本実施場所は，大規模なバスターミナルが設置され ているため, バス利用者が比較的多いと考えられる。一 方，岡山市民の待ち合わせの場所としても機能しており， 普段バス利用をしない人々も多く集まる場所である.

調査方法は，基本的には調査員がサポートしながら， 被験者自らが記入する方法（自己記入方式）により実施 したが，被験者の状況にあわせて，調査員が聞き取り， その内容を調查員が記入する方式も採っている. 調査票 の項目は，日常的な自動車利用やバス利用の頻度及び䒼 足度，個別のバスサービスに対する意識などを問う設問 を作成している，なお，アンケート被験者の中には，県 外からのビジネス客や観光客も含まれていたが，例えば 三大都市圈と岡山市のような地方都市の居住者とでは, 他の交通手段の整備状況や公共交通に対する個人の意識 などが大きく異なることが考えられる，このため，本研 究では，これら個人のバス利用環境などに配慮して，全 アンケート被験者のうち「岡山市内」の居住者227サン プルを対象に分析を行っている. 本研究で用いたアンケ 一ト調查における被験者の個人属性を図-1に示す．各属 性において，満遍なくサンプルが得られているものの， 岡山駅駅前で実施した特性上，通勤・通学者の割合が高 い一方で，高齢者の割合が低くなっている．本論文の分 


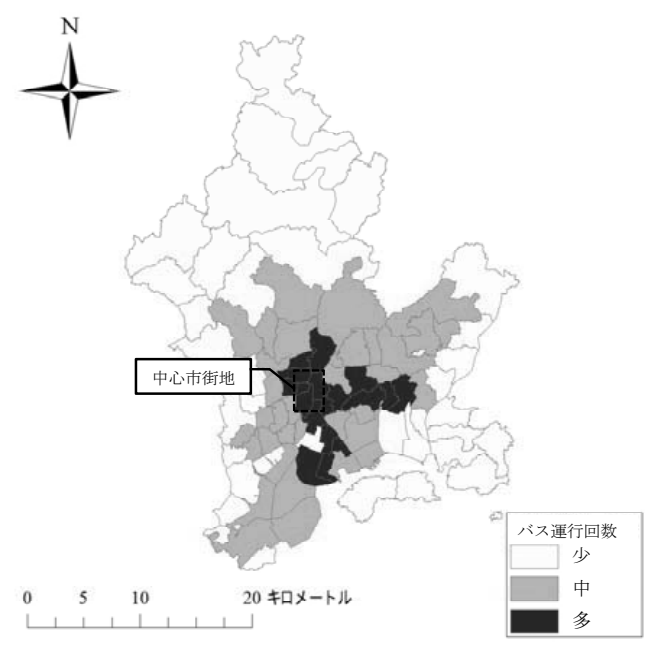

図-2小学校区ごとのバス運行回数 (岡山市)

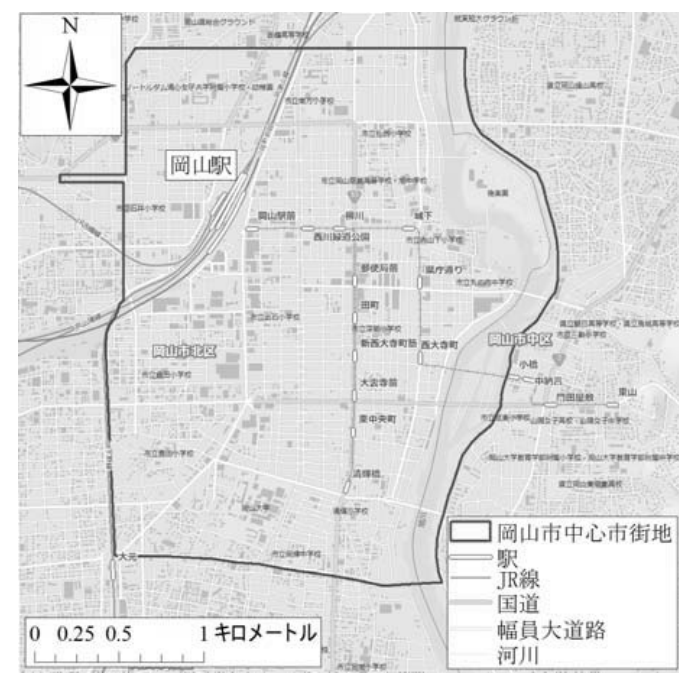

図-3 岡山市の中心市街地

析では，年龄階層や職業の有無等に配慮して分析を進め ているが，サンプル数に偏りがあるため，個々の属性別 の詳細な検討（例えば，高齢者の通院目的のバス利用な ど）や得られる知見については，分析上の限界があるこ とに留意する必要がある.

なお，以降の分析で用いる「バス運行回数」は，岡 山市都市整備局街路交通課より提供頂いた岡山市の町丁 目別バス便数データ9を用いることで小学校区単位のバ ス運行回数を算出し，「居住地」の回答結果を基に被験 者を3つのグループに分類した. 分類基準は，平日にそ の小学校区のバス停1か所にバスが停車する平均回数が0 〜49回のときを「少」，50〜100回のときを「中」，101 回以上のときを「多」としている. これを図化したもの を図-2に示す.また, 「通勤・通学先が中心市街地」は,
岡山市都市ビジョン ${ }^{10}$ の中で定義されたものを利用し，

「居住地」の回答結果を基に被験者を2つのグループに 分類した. この中心市街地を図-3に示す.

\section{4. アンケート調査に基づく分析結果}

\section{(1) バス利用の有無に関する要因分析}

本節では，バス利用への転換可能性の前段階として, まず自家用車利用の有無にかかわ加ず，どのような特性 の人々がそもそもバスを利用しているのか，あるいは利 用していないのか，それら現状を把握する。具体的には， アンケート調査結果に基づき，バス利用の有無と個人の 属性（年齢，職業，居住年数，自動車利用頻度など）や バス利用環境（バス運行回数や最寄バス停までの所要時 間）との関連性を，数量化類モデルを用いて明らかに した。なお，1年に少なくとも1回以上バス利用経験があ ると答えた被験者を「バスを利用する」，それ以外の被 験者を「バスを利用しない」としている.また，岡山市 在住の227サンプルのうち，居住地や通勤先などが不明 なサンプルを除いた142サンプルを対象としている.

分析の結果を図-4に示す。まず，偏相関係数が最も高 いのは「バス運行回数」で，次いで「年齢（職業）」，

「最寄りのバス停までの所要時間」が高く，これらが特 にバス利用の有無に影響を及ぼしている，つまり，バス 利用の有無については，居住地のバス整備状況（「バス 運行回数」や「バス停までの所要時間」）が大きな影響 を与えている．個別にみると，バス運行回数が相対的に 少ない地域では，バスを著しく利用しない傾向にあるも のの，バス運行回数「中（バス停車回数 $50 １ 00$ 回/ 日）」と，「多（バス停車回数101回/日以上）」では, バス利用の有無に大きな差が見られないことも読み取れ た. その他，「年齢 (職業)」では，若年の「勤め人」 や60代未満の「非勤め人」が，「自家用車の利用頻度」 については，「外出時は大抵利用する」と回答した層が， バスを利用しない傾向にあった。

\section{（2）バス利用への転換可能性に関する要因分析}

本節では，前節と同様に個人のバス利用環境に着目し て, 自家用車利用からバス利用 の転換可能性との関連 を数量化林類モデルを用いて明らかにする. これにより， どのような属性が，バス利用への潜在的な転換可能性を 有しているのかについて把握する。 なお，調査票におい て，バスサービスが改善されたとき，自家用車利用から バス利用へ「転換する」と「転換する可能性は高い」と 答えた被験者を「転換可能性がある」，「転換する可能 性は低い」と「転換しない」と答えた被験者を「転換可 能性はない」として用いている，また，本分析では，送 


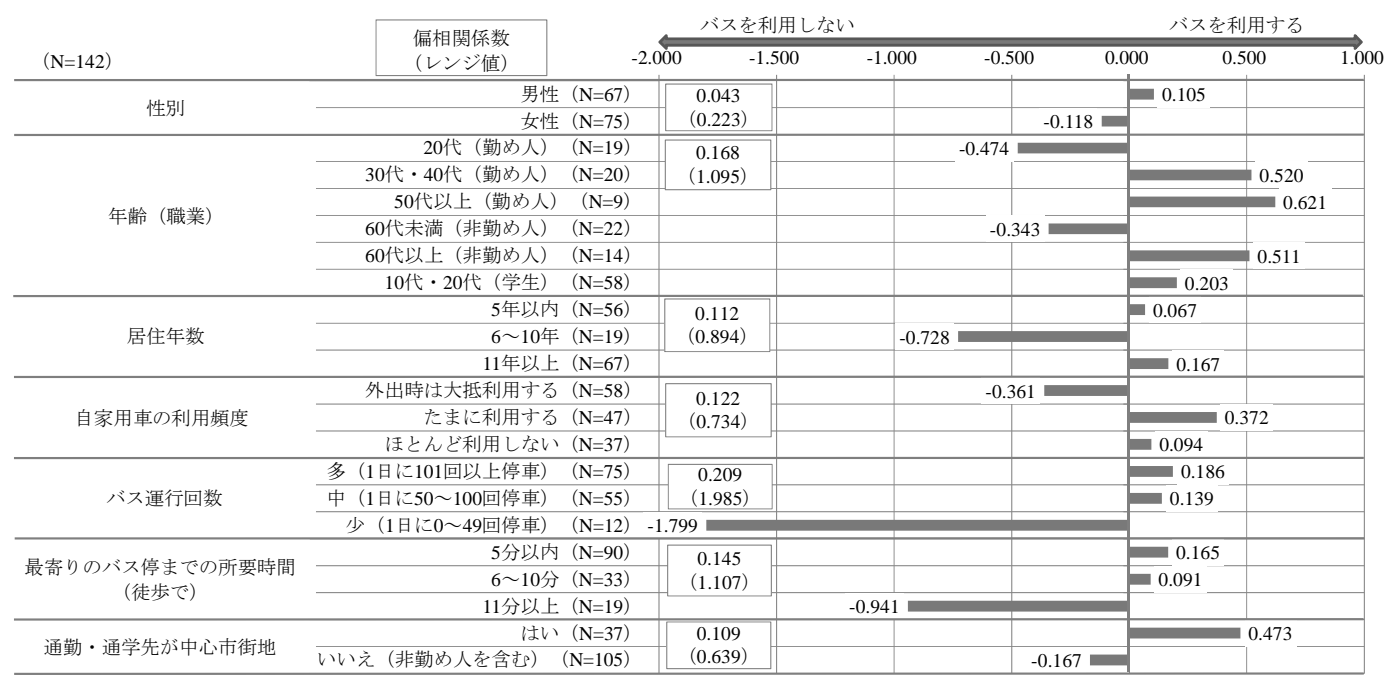

\begin{tabular}{|c|l|c|}
\hline \multirow{2}{*}{ 目的変数の重心 } & バスを利用する $(\mathrm{N}=99)$ & 0.245 \\
\cline { 2 - 3 } & バスを利用しない $(\mathrm{N}=43)$ & -0.563 \\
\hline \multicolumn{2}{|c|}{ 相関比 } & 0.139 \\
\hline \multirow{2}{*}{ 判別的中率 } & $66.9 \%$ \\
\hline
\end{tabular}

図-4 バス利用の有無に関する要因モデル

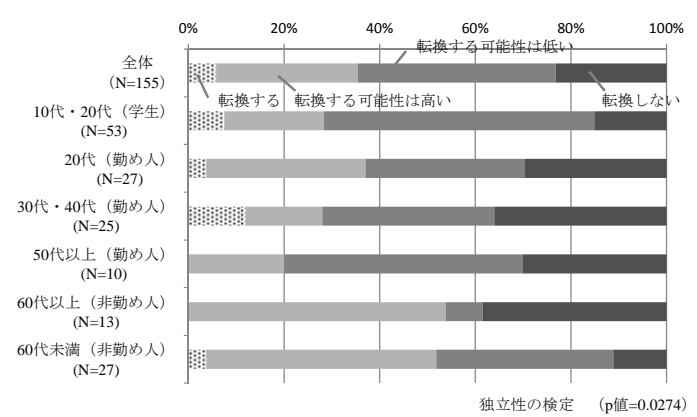

図-5 バス利用への転換可能性の構成割合

迎も含め，自家用車を利用している被験者を対象として いる，なお，本調查では，個別のバスサービスに対する 改善度合いを具体的に設定していない.これは，1)改善 度合いは，個別のバスサービス内容によって全て異なる， 2)それら度合いを同じレベルで統一寸ることも困難であ るためである.このような制約のもと，本研究では，そ もとも被験者の意向としてバス利用一の転換を考える素 地はあるのか，その場合にどのようなバスサービスの改 善が重視されるのかを伺っている.

図-5にバス利用一の転換可能性の構成割合を示す，バ スサービスが改善された際に，バス利用へ「転換する」 あるいは「転換する可能性が高い」と回答した層は約 35\%に留まっている，また，個人属性間では，その構成 割合に有意差が見られ，非勤め人の転換可能性が相対的 に高いものの，50代（勤め人）で低くなっている.
たとえバスサービスが改善されたとしても，自家用車 利用からバス利用への大幅な転換は，自動車依存型の都 市構造の中で, 自動車利用が習慣化した岡山市では容易 でないことが読み取れる。これら傾向は，鉄道やバスな どの公共交通網が不十分で，このため自動車依存度の高 (地方都市11212)でも同様の傾向であることが類推される．

次に，図-6にバス利用への転換可能性に関する要因モ デルの結果を示す，なお，自家用車利用からの「転換可 能性」に関する項目に未回答あるいは，居住地，通勤先

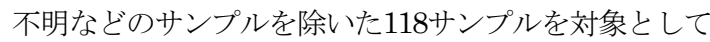
いる.

偏相関係数が最も高いのは「年齢（職業）」で，次い で「バス運行回数」，「居住年数」が高く，これらが特 にバス利用への転換可能性の有無に影響を及ぼしている 項目であることがわかる，バス利用の有無では，居住地 のバス整備状況が大きな影響を及ぼしたのに対して，年 齢や職業の有無，居住年数などの個人属性に関わる項目 の影響が大きい，具体的には，「年齢（職業）」では， 高齢の「勤め人」や「10代・20代（学生）」において, バス利用への転換可能性が低い傾向にあるが，年齢層問 わず「非勤め人」はバス利用への転換可能性が高い傾向 にあった.「バス運行回数」では, 少ない地域に住む層 ほど，「居住年数」では，短い期間の層ほどバス利用へ の転換可能性が低い傾向にあった。また，「自家用車の 利用頻度」を見ると, 自家用車への依存度が転換可能性 の有無に影響を与えていることが分かる. 


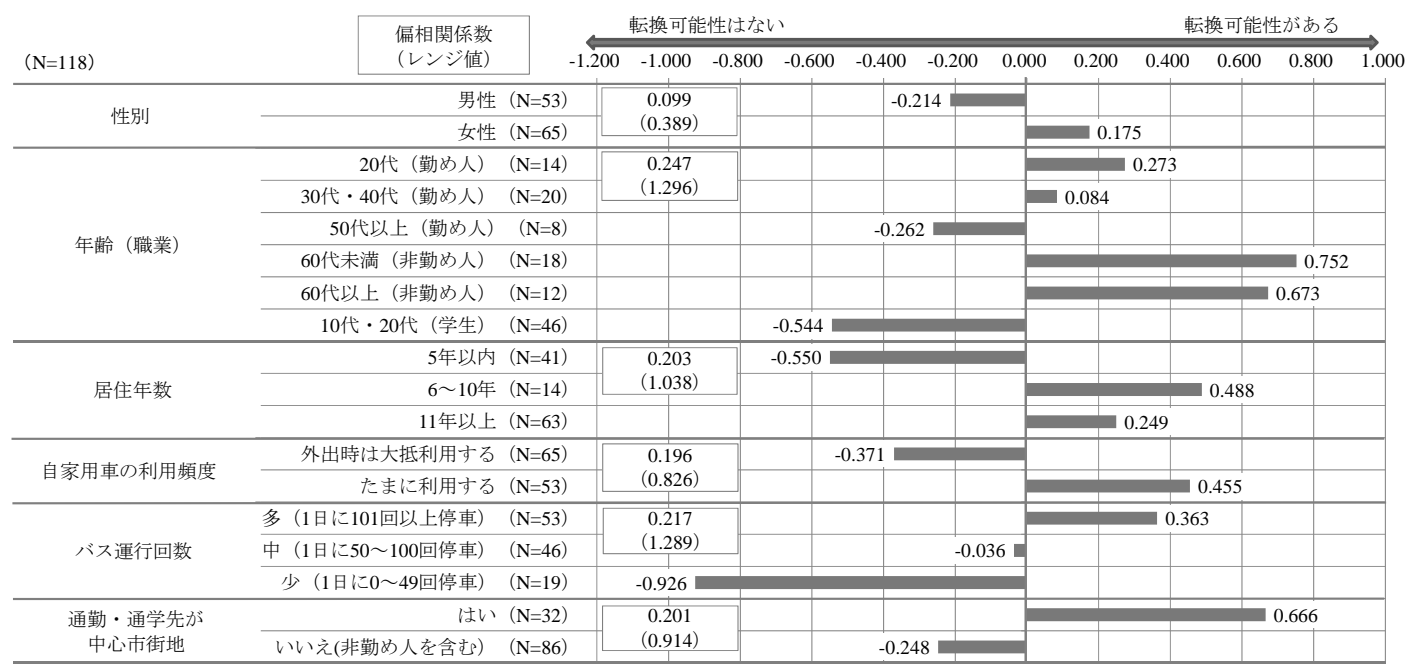

\begin{tabular}{|l|l|c|}
\hline \multirow{2}{*}{ 目的変数の重心 } & 転換可能性がある $(\mathrm{N}=39)$ & 0.657 \\
\cline { 2 - 3 } & 転換可能性はない $(\mathrm{N}=79)$ & -0.324 \\
\hline \multicolumn{2}{|c|}{ 相関比 } & 0.215 \\
\hline 判別的中率 & $69.5 \%$ \\
\hline
\end{tabular}

図-6 バス利用への転換可能性に関する要因モデル

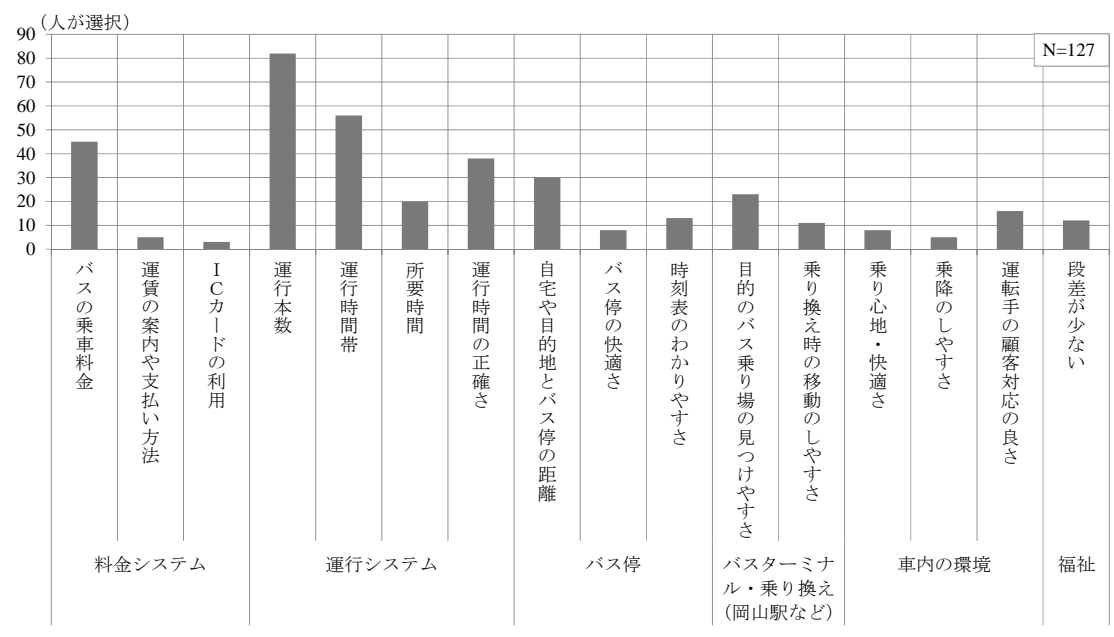

図-7 バス利用へ転換する際のバスサービスに対する改善ニーズ

(3) 自家用車利用からの転換のためのバスサービス改

\section{善ニ一ズの検討}

本節では，まず，a)自家用車利用からバス利用への転 換を考える場合に改善が求められるバスサービスの全体 的な傾向を，単純集計により明らかにする. 次に, b)外 部観察可能な個人属性に着目して，個別のバスサービス に対する改善ニーズを，後述するコレスポンデンス分析 を用いて明示する，個人属性としては，「年齢（職 業）」を採用した。その理由としては，1)外部観察の可 能 (容易) な変数であるため, 例えばヒアリング調査等
を実施せずとも，バスサービス改善のための施策を検討 できる，2)前節のモデル分析の結果からも偏相関係数の 最も高かった変数であること, つまり, バス利用への転 換可能性の有無に最も影響を与える変数であることが挙 げられる．本分析では，バス利用への転換可能性のうち，

「転換する」，「転換する可能性は高い」，「転換する 可能性は低い」と回答した（つまり, 転換可能性が少し でもある）サンプルで，かつ，転換する場合に改善して 欲しいサービスを回答した127サンプルを対象とした.

また，コレスポンデンス分析とは，集計されたクロス 


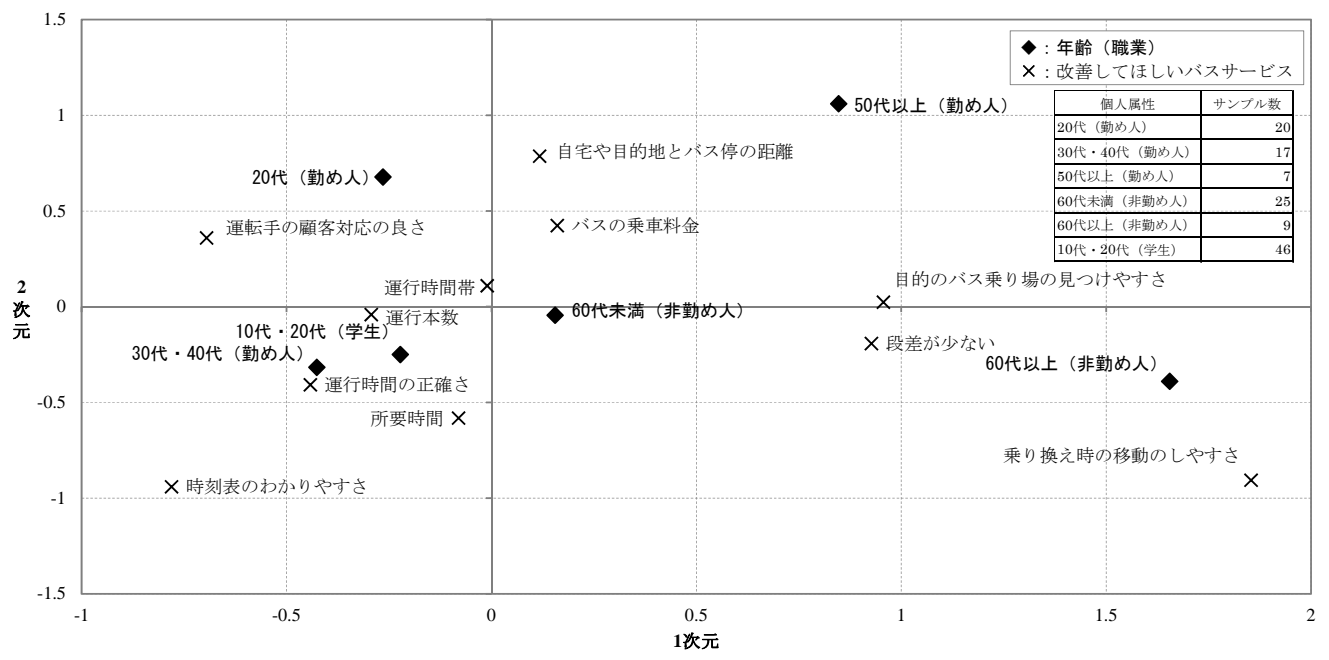

図-8 年齢 (職業) とバス改善ニーズとの関係

表-2 分析結果の固有值表及び検定結果

\begin{tabular}{|c|c|c|c|c|c|c|c|}
\hline 軸 & 特異值 & 固有值 & 需与率 & 累積寄与一率 & カイ二乗値 & 自由度 & $\begin{array}{l}\mathrm{P} \\
\text { 值 } \\
\end{array}$ \\
\hline 第1軸 & 0.292 & 0.085 & 0.504 & 0.504 & 30.006 & 14 & 0.008 \\
\hline 第2軸 & 0.184 & 0.034 & 0.200 & 0.704 & 11.583 & 12 & 0.480 \\
\hline 第3軸 & 0.168 & 0.028 & 0.167 & 0.870 & 9.628 & 10 & 0.474 \\
\hline 第4軸 & 0.131 & 0.017 & 0.102 & 0.973 & 5.873 & 8 & 0.661 \\
\hline 第5軸 & 0.068 & 0.005 & 0.027 & 1.000 & 1.558 & 6 & 0.956 \\
\hline
\end{tabular}

集計結果を基に，その行要素と列要素のすべてのカテゴ リから性質の似たものをまとめるために用いられる分析 手法である。

\section{a) バスサービスに対する全体的な改善ニーズ}

単純集計の結果を図-7に示寸，なお，分析で用いる 「改善してほしいバスサービス」は, 調査において, バ ス利用への転換可能性が少しでもあると回答した層が， 16項目から3項目を選択している.

分析結果より，「運行本数」や「運行時間帯」，及び 「バスの乗車料金」への改善ニーズが全体として高いこ とが分かる。これらバスサービスは，バス利用者数の低 下によって，事業者側がまずサービス低下を余儀なくさ れる項目であり，バス利用者側と事業者側のジレンマが 見て取れる．言い換えれば，全体としてのニーズは高い ために，これらサービスの改善により，利用者の大幅な 増加が見込める可能性もあるとも言える. 以降の分析 では，バス利用への転換可能性の有無に最も影響を与え る変数である年齢（職業）に着目して，個別の改善ニー ズを明らかにすることにより，バス利用一の転換に向け た施策を効果的に実施するための知見を得ることとする．

\section{b) バスサービスに対する個別の改善ニーズ}

次に，詳細な個別のニーズを把握するために，個人属 性“年齢 (職業)”に着目して，コレスポンデンス分析
を実施した結果を図-8に示寸。“年齢（職業）”はこれ までの分析と同様に，年齢と職業をクロスさせ，両指標 を反映した分類を用いている．なお，分析精度の問題か ら, 各項目について, 選択人数が一桁のものは除いてい る．また，3. でも述べたように，本アンケート調查の サンプル特性として，高齢者のサンプル割合が低いなど の偏りが見られた。このため，例えば，通院目的の高齢 者サンプルがほとんど含まれていない等，本分析から得 られる知見には限界があることに留意する必要がある。

この分析結果の固有值表及び検定結果を表-2に示寸. この表より，2次元までで累積寄与率が約70\%となり， この2軸で元の情報をおおむね説明できていると言える。 この散布図では, 各層が最も改善してほしいものが近く なる訳ではなく，その他の層と比較して，相対的に相関 が高いものが近くにプロットされる.

分析結果より，「10代・20代（学生）」と「30代・40 代（勤め人）」は，相対的に類似した改善ニーズを有し ていることが確認できる，一方，「60代以上（非勤め 人）」は，他の層と離れた位置にプロットされており， このためバスサービスの改善ニーズが特殊であると言え る.また，1次元に着目すると，負の方向では相対的に 若年が，正の方向になると高齢になっている．若年側で は,「運行時間の正確さ」や「所要時間」,「運転手の 顧客対応の良さ」など乗車時に影響を及ぼす運行システ ムに関するカテゴリがプロットされており，高齢側では， 「乗り換え時の移動のしやすさ」や「段差が少ない」，

「目的のバス乗り場の見つけやすさ」など乗車前後の負 担に関するカテゴリがプロットされていることがわかる。 そのため，若年層に対しては，乗車時に関する項目の改 善が有効で, 高齢層に対しては, 乗車前後の項目の改善 が有効であると言える。このように，図-7の単純集計結 
果から，全体として見た場合に，「運行本数」や「運行 時間帯」などの改善ニーズが高いことが分かっているが, 個人属性でみれば，それぞれ特有の傾向があることが分 かる. 言い換えれば, バスの運行時間帯や運行ルートに よっては，乗客の属性にある程度偏りがある場合などに は，それぞれ求められるバスサービスを効率的に実施し ていくことも考えられる.

また，別の視点からは，図-6にて示したバス利用への 転換可能性の高低に着目寸ることにより，バスサービス の改善にプライオリティーを付けて実施していくことも 有効と言える．これは，比較的容易に転換が見込める層 が求めるバスサービスの改善をまず実施することにより, バス利用者数を増加させることが狙いである. 具体的に は, バス利用への転換可能性の高い層である若年の「勤 め人」では,「運転手の顧客対応の良さ」や「運行時間 の正確さ」の改善が有効であり,「60代以上（非勤め 人）」では，「段差が少ない」や「乗り換え時の移動の しやすさ」の改善が有効となる。 また，バス利用への転 換可能性が高い傾向にあった「60代未満（非勤め人）」 は，原点付近にプロットされているが，これは比較的回 答が分散しているためである. また, 原点付近にプロッ トされている「運行時間帯」は, クロス集計結果より, 全体的に同じような選択割合であることが分かっており， どの層に対しても同様の効果を期待できる.

\section{5. おわりに}

本研究では，自家用車利用からバス利用への潜在的な 転換可能性や，その際のバスサービスの改善ニーズを， 居住者のバス利用環境の視点から定量的に明らかにした.

分析の結果から, バス利用の有無は, 居住地のバス整 備状況の影響が相対的に大きく, バス利用への転換可能 性は，年齢や職業の有無の影響が大きい. なお，これら 分析結果は, 現状において, どの地方都市でも見られる 自家用車利用の習慣化 ${ }^{1112)}$ の中で，「利用を控える」と いら行為に対して, 同様の傾向が見られることが類推さ れる. また, 個別のバスサービスに対する改善ニーズに ついては, 職業の有無に関わらず40代以下の層は，相対 的に類似した改善ニーズを持つ一方，60代以上非勤め人 の層は極めて特徴的な改善ニーズを有していた．また， バス利用一の転換可能性の高い若年層勤め人は，運転手 の顧客対応の良さや運行時間の正確さなどを求める傾向 にある反面，同様に高い60代以上非勤め人は，段差の少 なさや乗り換え時の移動のし易さなどを求めている。 こ のように, 外部観察可能な個人属性に着目してバスサー ビスの改善ニーズを分析することにより，個別の運行ル ート及び運行時間帯, さらにはバス事業者固有の事情
(資金面や現在の取組み状況等) などに合わせて，プラ イオリティーを付けて, 有効な施策を展開していくこと が可能となる. なお, 本分析では, 他都市においても適 用可能なように，地域性より汎用性を重視した内容にな っている. このため, ある地方都市の特定の路線のみを 取りあげて検討する場合には, バスサービスの改善ニー ズに関しては，そのバス路線の状況を考慮した上で，本 分析の結果を解釈寸る必要がある. また, 本研究でいく つか構築した要因モデルの説明力はいずれもあまり高く ない.これらは, 本研究で用いた説明変数以外の要因が 影響していることを示唆している. その要因の中には, 例えば，倉嶋ら の研究にある個人が持つ感覚的な「バ スイメージ」も影響していると考えられる. 今後, これ ら他要因についても検討していくことが望まれる.

謝辞 : JR岡山駅の駅前広場で実施した調査は, 岡山市都 市整備局街路交通課の多大なる協力によって実現したも のである. また, 調查にご協力頂いた486名のJR岡山駅 の駅前広場利用者の皆様, 岡山大学地域環境計画学研究 室の学生を含め, 多くの方々の協力を得た. ここに記し, 深謝の意を表す.

\section{参考文献}

1) 交通エコロジー・モビリティ財団：運輸・交通と環 境, 2011 年度版.

2) 堺市建築都市局 : 堺市の交通ビジョン, http://www. city.sakai.lg.jp/city/info/_koutuseisaku/koutu_vision_05_ 02_03.html，2012.7.3 最終閲覧

3) 岡山市: 平成 23 年版 岡山市の交通概況（3）公共交 通, http://www.city.okayama.jp/contents/000096450.pdf, 2011.11 最終閲覽.

4) 遠藤玲, 中川義也, 荻田聡, 中村文彦: 交通手段固 定層類型別手段選択モデル適用によるバス利用促進 施策の評価, 土木計画学研究・論文集, Vol.21,

No.3, pp.657-665, 2004.

5) 高木昌也, 奥嶋政嗣, 近藤光男 : 地方都市のバス利 用促進のための行動意図法による潜在需要分析, 都 市計画論文集, No.45-3, pp.439-444, 2010.

6) 萩原剛, 藤井聡 : 行動プランデータを用いた自動車 利用抑制のための行動変容形態に関する分析, 土木 計画学研究・論文集, Vol.22, No.3, pp.461-466, 2004.

7) 倉嶋祐介, 近藤隆二郎 : 利用頻度に着目した路線バ スイメージの分析, 土木計画学研究・講演集, Vol.44, CD-ROM, 2011.

8) 佐藤良太, 谷口綾子 : バス利用者のバス利用満足度 に接客サービスが与える影響に関する研究, 土木計 画学研究・論文集第28巻, Vol.67, No.5, pp.I_1149- 
1155, 2011.

9) 岡山市都市整備局街路交通課 : 岡山市町丁目別バス 便数データ，2011.9.

10)岡山市: 岡山市都市ビジョン【新・岡山市総合都市 計画】, http://www.city.okayama.jp/kikaku/kikaku_ 00164.html, 2011.12最終閲覧.

11）谷口守，松中亮治，平野全宏：都市構造からみた自
動車 $\mathrm{CO}_{2}$ 排出量の時系列分析, 都市計画論文集, No.43, pp.121-126, 2008.

12）平野全宏，中道久美子，谷口守，松中亮治：都市別 自動車 $\mathrm{CO}_{2}$ 排出量の定量化とその経年変化分析, 環 境システム研究論文集, Vol.36, pp.19-26, 2008.

\section{POTENTIALITY FOR MODAL CHANGE FROM PRIVATE VEHICLES TO BUSES AND NEEDS OF BUS SERVICE}

\section{Takehito UJIHARA, Hirofumi ABE and Tomoya KASHIMURA}

To maintain regional transportation for dependent users, the use of buses and the quantitative increase or stabilization of bus users are necessary. It is important to convert the means of regional transportation from private vehicles to buses to reduce the environmental load. The potentiality of the bus mode of transportation must be reviewed. Therefore, based on results of research conducted at Okayama Station, we conducted investigations into the actual conditions of buses to analyze factors determining whether buses are used and whether a change over from private vehicles to buses as a means of regional transportation can be accomplished. The results acquired in this study suggest an effective policy to advance the change from private vehicles to buses. Results show a quantitative relation of bus use to age and occupation. The major results are as follows. 1) Potentiality for modal change to buse is specially influenced by age and occupation.2) As for needs of bus service, whereas needs of under 40s are the number of lines and the accuracy of timetables, needs of over 60s(unemployed) are the reduction in burden of boarding and transfer. 